\title{
A gyermekkori játéktevékenységre való visszaemlékezés és a felnóttkori félelmek kapcsolata: játék zárt helyen és a szabadban
}

\section{KÁLLAI JÁNOS ${ }^{1,5 *}$ - RÓZSA SÁNDOR ${ }^{2}$ - HUPUCZI ERNŐ ${ }^{1}$ - MARTIN LÁSZLÓ ${ }^{3}$ - VINCZE GÁBOR ${ }^{4}$ - LÉNÁRD KATALIN ${ }^{5}$ - TÖRÖK IMRE ANDRÁS ${ }^{6}$}

${ }^{1}$ Pécsi Tudományegyetem, Általános Orvostudományi Kar, Magatartástudományi Intézet, Pécs

${ }^{2}$ Department of Psychiatry, Washington University School of Medicine, St. Louis, USA

${ }^{3}$ Kaposvári Egyetem, Pedagógiai és Pszichológiai Tanszék, Kaposvár

${ }^{4}$ Békés Megyei Pándy Kálmán Kórház, Pszichiátriai Osztály, Gyula

${ }^{5}$ Pécsi Tudományegyetem Bölcsészettudományi Kar Pszichológiai Intézet, Pécs

${ }^{6}$ Semmelweis Egyetem, Alkalmazott Pszichológiai és Egészségtudományi Tanszék, Budapest

(Beérkezett: 2017. október 6.; elfogadva: 2018. január 7.)

Elméleti háttér: A téri tájékozódással kapcsolatos korai vizsgálatok eredményei szerint a szabadban zajló játék során megszerzett képességek, gyermek és felnőtt korban egyaránt csökkentik az idegen helyekre vonatkozó félénkséget. A gyermekkori játéktevékenység és a felnőttkori félelmek összehasonlító vizsgálatát azonban nehezíti a játéktevékenység kulturális sokszínúsége és a hosszmetszeti vizsgálatok lebonyolításának nehézségei. Módszer: A jelen vizsgálatban a gyermekkori játékhelyzetekre való visszaemlékezés alapján feltárt játéktípus és helyszínpreferencia adatokat a személyek felnőttkori félemeinek típusával és mértékével vetettük össze. A vizsgálatában 365 nő és férfi egyetemi hallgató vett részt. Egy korábbi hazai vizsgálat keretében azonosított, zárt helyen és szabadban zajló 21 játékaktivitás típus elemzése során statisztikai eszközökkel, a játék helyszíne alapján jól elkülöníthető csoportokat képeztünk. Eredmények: Megállapítottuk, hogy a szabadban zajló játék, fizikai megmérettetést igénylő test-test elleni küzdelem és közösségteremtő játéktípusokra osztható. A zárt térben pedig a szerepjátékok, a szociális és kognitív konstrukciós típusú játékok a jellemzők. Fiúk a test-test elleni, a lányok a közösségépítő szabadban zajló játékokat kedvelik. A zárt térben folytatott játékok esetében fiúk a szerep, lányok inkább a konstrukciós típusú játékokat preferálják. Megállapítottuk, hogy nemtől függetlenül, a zárt helyen zajló szerepjáték preferenciák az állatokkal, szociális, és szexuális jelenetekkel kapcsolatos félelmek alacsony értékeivel mutatnak összefüggést. A szabadban

\footnotetext{
* Levelező szerző: Dr. Kállai János, Pécsi Tudományegyetem, Általános Orvostudományi Kar, Magatartástudományi Intézet, 7624 Pécs, Szigeti út 12. E-mail: janos.kallai@aok.pte.hu
} 
zajló fizikai és társas kapcsolati kihívások preferenciája pedig alacsony agorafóbiás értékekkel jár együtt. Következtetések: a gyermekkori játék színhelye és játéktípus preferencia mértéke, valamint a felnőttkori félelmeket kiváltó helyzetekre vonatkozó érzékenység összefügg egymással.

Kulcsszavak: agorafóbia, játék, félelem, környezet, biológiai nem, zárt helyen, szabadban

\section{Bevezető}

Szülő és gyermek közös játéka nemcsak a gyermekre, hanem a szülő személyiségfejlódésére is komoly hatást gyakorol. Az anya, gyermeke autonómia törekvéseit támogatva megtanulja, hogy feleslegesen ne akadályozza ôt, hagyja érvényesülni a társaival való játék során (Barcsi és mtsai, 2017; Kerns, Tomich, \& Kim, 2006; Mérei és V. Binét, 2006). A gyermek és a szülő kreatív kapcsolata leglátványosabban félelmektől mentes játékkörnyezetben teljesedik ki (Hámori, 2015; Hendricks, 2015). A családi kapcsolatok eróziója akadályozza a képességek, szerepek és szociális kapcsolatok kiépítését, továbbá korlátozza a szabad játék kibontakozását, valamint az otthontól távoleső, a szülők felügyelete nélkül zajló játék lehetőségeit. Napjainkban, az évtizedekkel korábban rendelkezésre álló játszóhelyek szúkösségéből fakadó szocializációs hátrányok azonban számos várható nehézségre figyelmeztetnek (Holt, 2016). A hátrányok megmutatkozhatnak a gyermekkori szorongások, fóbiák és ezek következtében kialakuló felnőttkori félelmek megjelenésében (Bowlby, 1973). Jelen vizsgálatban a kisiskolás korra való visszaemlékezésból származó játékpreferencia-adatokat és a különböző felnőttkori félelmekkel kapcsolatos személyes érzékenység, veszélyeztetettség mértékét vetjük össze.

\subsection{Korlátozó és fejlesztő környezeti feltételek a gyermekkori játék kiteljesedésében}

A játék örömforrás, amely alkalmas a motoros, és a kognitív funkciók, illetve a szociális szerepek gyakorlására, az új dolgok kipróbálására, a személyes alkotókedv kibontakoztatására, a ritmus, az ismétlődés, az együttes élmény mély átélésére (Mérei \& V. Binét, 2006). A játék kettős világ, amely hidat képez a valóság és a képzelet között és ezzel lehetőséget teremt a veszélyes helyzetekkel szembeni védekezés gyakorlására az esetleges félelmek semlegesítésre (Piaget, 1962), átvezet az egyik fejlődési zónából a következő felé (Vigotszkij, 1971), miközben megteremti azt a közeget, amely a felnőttkor igazi érvényesülési terét képezi (Wallon, 1971). Az életkor, a játék fejlődéstani funkciója és az alkalmazott játéktárgyak köre alapján különbö- 
ző csoportosítási formák érvényesek: funkciógyakorló-, konstrukciós-, explorációs-, dramatikus-, vagy szerepjátékok, zárt helyen vagy szabadban, épített vagy természetes játszóhelyeken folytatott játékok, amelyek közül életkori megjelenés szerint, hol az egyik, hol a másik válik uralkodóvá (Cosco és mtsai, 2010; Smilansky, 1968; Zahra, 2016).

Idegen vagy veszélyes helyek felderítése során szerzett tapasztalatok elősegítik a felnőttkori érzelmi kiegyensúlyozottságot. A játéktér felderítése során szerzett tapasztalatok hosszútávú pozitív hatásai támogatják az önkontroll fejlődését és növelik a traumákkal szembeni ellenállóképességet (Harker, 2005). A városi és a természetes játéktér lehetővé teszi az elvonulást, elrejtőzést, a kitörést, majd a védelembevonulást, a koalícióalkotást és az általános problémamegoldó tevékenységek gyakorlását (Herrington, 2007; Pellegrini, 2009). A városi és a természetes környezetben zajló tevékenység során a biztonságot kínáló helyekkel és személyekkel digitális eszközökön keresztül fenntartható képi és auditív kapcsolat a gyermekek számára kibővíti a környezet explorációjának lehetőségeit. Más vonatkozásban azonban korlátozza a személyes felelősségre és önkontrollra épülő tapasztalatszerzést, továbbá a digitális kapcsolat megszakadása új félelmek (nomophobia) és dependenciák kialakulását eredményezik (Dúll, 2010; Kállai, 2013; King és mtsai, 2010; Lepp és mtsai, 2014; Roberts és mtsai, 2014; Török és mtsai, 2010). Napjainkban a gyermekek kevesebb időt töltenek a szabadban, mint évtizedekkel ezelőtt (Valentine \& McKendrick, 1997), szívesebben vannak otthon a számítógép elótt (Clements, 2004). Ennek egyik oka a közvetlen és a tágabb környezettel kapcsolatos bizonytalanság fokozódása (Gelenn és mtsai, 2012), a városi környezet veszélyesebbé válása (Holt és mtsai, 2016). Az alacsonyabb népsürüségú és kevésbé forgalmas, búnügyi szempontból is kedvezóbb kisvárosi környezet támogatóbb az otthontól messzebb lévő, szabadban zajló játéktevékenység számára (Kyttä, 2006).

\subsection{A szabadban zajló játéktevékenység személyiségfejlődésre gyakorolt hatásai,}

a környezet által kínált lehetőségek és a személyes beállítódások összefüggésében

A veszély elkerülése, a biztonságos helyek megközelítése, és a szabadban zajló játék kiemelt szerepet kap az otthontól távoli környezet megismerésében és a személyes adaptációs lehetőségek kiteljesedésében (Kyttä, 2003; Lester \& Maudsley, 2007). Más tanulmányok a gyermekek motoros funkcióinak fejlődése és a fizikai egészség fenntartása szempontjából emelik ki a spontán szabadtéri játék meghatározó szerepét (Herrington \& Brussoni, 
2015; Spencer \& Wright, 2014). Prezza és munkatársainak (2007) eredményei szerint azok a gyermekek, akik többet játszanak szabadban, általában többet játszanak házon belül is kortársaikkal. A szabadtéri játéktevékenység mozgási territóriumának nyitottsága elősegíti a kortársak közötti kötődést, a kölcsönös felelősség, bizalom és segítőkészség fejlődését, és a természeti környezethez való pozitív viszony kialakulását (Kong, 2000). A mobilitás tiltása azonban visszafogja a képességek fejlődését. London központi területein, az alacsony jövedelmú családok erősebben korlátozzák a gyermekek mobilitását, a gyermekek kötődése a közvetlen lakókörnyezethez kisebb, környezetükben kevesebb kedvenc helyet neveznek meg. A játékra alkalmas helyhez való érzelmi kötődés a szülői korlátozó vagy támogató magatartással is kapcsolatot mutat (Corbishley, 1995). A vidéki, ritkán lakott helyen élő gyermekek számára a természeti helyekhez való kötődés erősebb, mint a társas helyek iránti érdeklődés (Matthews és mtsai, 2000).

\subsubsection{A független mobilitás jelentösége}

A függetlenebb mobilitással rendelkező gyermekek könnyebben felismerik a környezet által kínált lehetőségeket, idegen helyeken, szabad terepen jobban feltalálják magukat (Hüttenmoser \& Degen-Zimmermann, 1995). Érdemes azonban figyelembe venni, hogy a független mobilitási kompetenciák kialakulását a szülők által felügyelt játéktevékenység alapozza meg. Következésképpen a támogató, elutasító vagy korlátozó szülői magatartás befolyásolja a játékaktivitás minőségét és a játéktípusok preferenciáját. Erre a tényre utal Rissotto és Tonucci (2002) vizsgálata, amely szerint a mobilitás segíti a téri, környezeti tudás strukturálását, megszemélyesíti a helyet és gazdagítja annak motivációs forrásait. A fizikai paraméterekkel jellemezhető helyről származó kognitív és affektív tapasztalatok megalapozzák a személyes identitást, iránytúként szolgálnak a jelenben és utat mutatnak a jövő felé (Kállai, 2013; Kállai, Karádi, \& Tényi, 1998; Lalli, 1992; Proshansky és mtsai, 1983). A személyes környezet a maga történetével együtt a valahova tartozás kiindulópontja (Chawla,1992; Moore, 1986). A környezet egy pontjával, a hellyel való érzelmi kapcsolat fenomenológiai értelmezése szerint (Relph, 1976) a belül lenni (insideness) és a kívül lenni (outsideness) helyleíró fogalmak, a környezet megértésének és tudatosításának különböző szintjeit tárják elénk. A belül (inside) lenni érzés biztonságélménnyel jár, könnyedség, otthonosság melegség érzését idézi fel, támogató partnerek jelenlétét feltételezi. Ezzel szemben a kívül (outside) lenni érzés könnyebben kialakul új, szociálisan elszigetelt területeken és együtt járhat a szeparáció, a honvágy, az elutasítottság és az ellenségesség élményével. 


\subsubsection{A játéktevékenység tipizálása}

A független mobilitást kínáló környezettel kapcsolatos személyes élményeket értékelve Kyttä (2006) és Pyle (2002) vizsgálatai játékban, vagy más kedvelt aktivitásban megmutatkozó cselekvések esetében az alábbi hellyel való identitás típusokat emelik ki. 1. Az ideális Bullerby-típusú környezet: Åstrid Lindgren svéd író regényeiben szereplő típusos környezet, amely falusi közösséget ábrázol, ahol a gyermekek részt vehetnek a közösség életében, és külön a számukra tervezett játszó-, és védett területek nélkül elérhetnek különféle aktivitásformákat. A független mobilitás cselekvési lehetőségek sokaságát, fokozott explorációt eredményez. 2. A másik modell az úgynevezett Glasshouse-típus. A vonzó cselekvési lehetóségek száma nagy, de önálló játék során a környezet által kínált lehetőségeket a gyermekek csak korlátozott mértékeben képesek megvalósítani. Kyttä (2006) szerint ilyennek tekinthetók a régi európai típusú urbanizált települések, amelyek számos érdekes, felfedezni való dolgot tartalmaznak, ellenben veszélyesek, és ezért tiltottak a gyermekek számára (kísérőre, illetve folyamatos felügyeletre van szükség, oda kell szállítani a gyermeket). A veszélyérzet a szülői tiltás következményeként erősödik fel. A gyermekek temperamentumán és a szülők nevelési attitúdjén múlik, hogy a gyermek tud-e élni a lehetőségekkel. 3. A harmadik modell az úgynevezett Wasteland-típus. Ide sorolja Kyttä (2006) a nagyszámú külvárosi vagy elővárosi területet, amelyek vagy kiüresedtek, vagy olyan újonnan épült lakóparkok, ahol nem vették figyelembe a gyermekek és felnőttek szabadidejük eltöltésére vonatkozó igényeit. Ezeken a környékeken a tiltás szintje alacsony, az aktivitás viszonylag szabad, de a terület nem elég változatos és vonzó, helyenként kulturális szempontból "lepusztult", kevés fejlődési és kulturált társas érintkezési lehetőséget hordoz. A fejlődés alapvetően individuális erőforrásokon nyugszik, a közvetlen szülői támogatástól és a személyes karaktertől (félénkség, szorongás, bátorság, szociális kapcsolatkészség) függ. 4. A negyedik modell neve "Cell", amelyet a szabad önálló mobilitás erős tiltása jellemez, és lehetetlenné teszi a gyermekek számára az affordanciák észlelését, amelyek így nem is motiválhatják őket a környezet explorációjára. Ilyenek lehetnek a forgalmas városközpontok, a sok idegen jelenlétével, és az átmenő forgalommal jellemezhető területek. E tekintetben elsősorban a mobilitást visszafogó szülői magatartás és a büntetésérzékenység mértéke tovább korlátozza a szabadtéren zajló játék és navigáció lehetóségeit.

Az elméleti megközelítés módjától függően a játéktevékenység tipizálására számos egyébb lehetőség kínálkozik. Általánosan a csoportosítás alapját a játékot kiváltó motívumok természete, az affektív és kognitív fejlődésben ellátott feladatai, a felhasznált tárgyak, a résztvevő személyek, valamint a szociális kapcsolatok gyakorlásában betöltött szerepek határozzák meg. 
Továbbá a vélekedések, a személyes tapasztalatok, a nemi viselkedésre vonatkozó sztereotípiák is szerepet játszanak a csoportosításban. A játéktípusok csoportosítására számos paraméter figyelembevételével statisztikai eszközök is alkalmazhatók. Tisztában kell lenni azonban a csoportosításból adódó leegyszerúsítések veszélyeivel (Pellegrini, 2009).

\subsection{A szabadban zajló tevékenység során tapasztalt félelmek és felnőttkori következményeik}

A szülőktól távoli játéktér felderítése, a biztonságos határok és zónák kijelölése nemcsak a személyes szabadság érzésének átélését teszik lehetôvé, de biztosítják az önálló problémamegoldó-képesség fejlődését is (Pellegrini, 2009). A gyermekek számára a szomszédok, a család és a baráti kapcsolatok által kialakított védóháló kiterjedése azonban egyre kisebb, amelynek következményeként az aggódó szülők gyakrabban korlátozzák a gyermekek szabadtéri játéktevékenységét (Carver, Timperio, \& Craword, 2008; Holt, 2016). Az otthonon kívüli környezet jelentós része a szükséges affordanciák hiánya miatt kiesik a potenciális játékterek repertoárjából (Gibson, 1979; Kyttä, 2006).

A félelem nők és férfiak esetén egyaránt gátolja a tájékozódást (Kállai és mtsai, 2003). A 10-15 éves lányok a szomszédságukban lévő környezetben a fiúkhoz képest kevesebbet explorálnak, ismert környezetüktől kevésbé távolodnak el (Edwards, 2000; Matthews, 1986; Newson \& Newson, 1987). A magas félelemi értékekkel rendelkező szorongó nók gyermekkorukra visszaemlékezve úgy látják, hogy kevésbé hagyták el az otthonukat és korlátozottabb mennyiségú független exploratív tapasztalatot szereztek a környezetükról (Lawton \& Kállai, 2002). A lányoknak több veszéllyel kell szembenézniük, következésképpen a szülők aggodalmaik miatt gyakrabban ellenőrzik őket, ha játék közben kikerülnének a látókörükből. Félnek, hogy lányukat molesztálja valaki, visszaélnek gyengeségével és ártatlanságával (Newson \& Newson, 1987). A jogos veszélyek miatt a lányok félénkebbek a fiúknál. A fiúk is félnek ugyan az eltévedéstól, a veszélyes emberektől, állatoktól, fizikai sérülésektől, esetleg a társak előtti megszégyenüléstől, de velük kapcsolatban a szülők a bátorságot, a kitartást, az önálló problémamegoldó-képesség elsajátítását támogatják. Ettől függetlenül az ismeretlen játszóhelyek felderítése gyakran félelmek árnyékában zajlik. A biztonságigény, a menekülésre vagy a megküzdésre való felkészülés, és a félelem egyénre jellemző érzékenységtől függően együtt jár az idegen territórium meghódításának kreatív feszültségével (Cashdan és mtsai, 2016; Kruger \& Byker, 2009; Marks, 1987; Noyes \& Hoehm-Saric, 1998). 


\subsection{Hipotézisek}

A gyermekkori autonómia-dependencia-konfliktus megoldásának minősége a késóbbi felnőttkori félelmek és fóbiák iránti érzékenység egyik sarokköve (Frances \& Dunn, 1975). A gyermekkori félelmekból származó, bizonytalan helyzetekre vonatkozó téves interpretációk feloldásának feltételeit a szabadban végzett explorációs tevékenység, és a csoportos és egyéni játék során szerzett tapasztalatok biztosítják (Guidano \& Liotti, 1983; Jacobs \& Nadel, 1985; Kállai, 2013). A kisiskoláskorú gyermekek iskolai, valamint a felnőttek hobbi-, sport-, és játéktevékenysége által biztosított fejlődés elősegíti a félelmeket kiváltó helyzet megoldására való felkészülést (Marks, 1987). A fentiekben bemutatott ismeretek alapján jogos az a megállapítás, hogy a gyermekkori, otthon vagy szabadban zajló játékok preferenciája áttételesen ugyan, de bizonyos mértékig előrevetíti a felnőttkori félelmekkel kapcsolatos veszélyeztetettséget. Ezek alapján feltételezzük, hogy a játék színhelyének preferenciája nők és férfiak visszaemlékezéseiben jelentős nemi különbségeket fog mutatni. Várakozásaink szerint, a nők visszaemlékezéseikben elsősorban otthon, zárt helyen zajló játékok, míg a férfiak esetében otthontól távol, a szabadban végzett játékok preferenciája az erősebb. Másrészt a nemi különbségeken túl a játék közben szerzett tapasztalatok nemcsak a környezet megismerésének lehetőségeivel korrelálnak, de a felnőttkori aggodalmakkal, félelmekkel is kapcsolatban állnak. Feltételezésünk szerint a játékaktivitási formák színhely szerinti szelekciója differenciáltabb képet nyújthat a felnőttkori félelmek eredetének megértésében. Az elemzés elsó szakaszában a játéktevékenységre vonatkozó strukturált interjú gyakorisági adatai alapján kiemelt játékszínhelyeken belül főkomponens-elemzéssel differenciáljuk a játéktípusok fő faktorait.

A második részben pedig a feltárt játékkomponensek alapján megvizsgáljuk, hogy a játékszínhely, valamint a játékszínhelyeken belül elkülönített játéktípusok gyermekkori preferenciája milyen módon hozható összefüggésbe a felnőttkori félelmekkel.

\section{Módszerek}

\subsection{Résztvevők}

A vizsgálatban a Szegedi Egyetem és a Pécsi Egyetem különböző karairól (Általános Orvostudományi Kar, Bölcsészettudományi Kar, Természettudományi Kar) 365 egyetemi hallgató, hirdetményeken keresztül, önkéntes jelentkezés alapján, anonim módon, ellenszolgáltatás nélkül vett részt (232 
nő és 133 férfi). A résztvevők átlagéletkora 21,8 év (szórás: 2,3 év; terjedelem: 18-30 év). A vizsgálat a "Gyermekkori játékokra való visszaemlékezés és téri navigáció" címú projekt (Török Imre András) és a NKFI K-120334 pályázat (Kállai János) keretében készült. A vizsgált mintával kapcsolatos egyéb eredmények közlése más fórumokon folyamatban van. A vizsgálat a Helsinki Deklaráció alapelveinek figyelembevételével, megfelelő tájékoztatás mellett zajlott. A kutatást a Pécsi Tudományegyetem Regionális Kutatásetikai Bizottsága jóváhagyta (az etikai engedély száma: 4598).

\subsection{Mérőeszközök}

2.2.1. Zárt térben és szabadban zajló játék-preferencia mértékének felmérése. A vizsgálatban felhasznált adatok a „Gyermekkori játékokra való visszaemlékezés, és téri navigáció" projekt keretében végzett felmérésból származnak. Az alapvizsgálat adatait egy másik tanulmány keretében fogjuk közölni (Török, Rózsa, Hupuczi, Vincze, \& Kállai, elbírálás alatt). Az alapvizsgálat 57 fős önkéntesekből álló célcsoport strukturált interjúk segítségével feltárt adatait tartalmazza. A résztvevők visszaemlékezései alapján a 7-12 éves korra vonatkozó kedvelt játéktevékenységeket gyújtöttük össze. Az interjú részletes ismertetését lásd a Török és munkatársai (elbírálás alatt) tanulmányában. Az interjú anyagának feldolgozása után egy három főből álló pszichológus szakértői csoport a jelen vizsgálat szempontjából kiemelt témának megfelelően a játék színhelye alapján (zárt térben vs. szabadban zajló) két csoportba rendezte a játékaktivitás-formákat. Az interjúk nyomán kibontakozott 22 játéktevékenység közül 11 került a szabadtéri és 10 a beltéri csoportba. Az interjúkban játéktevékenységként említett tévézés vonatkozásában a szakértők nem jutottak egyezségre. A többség a tévézést nem tartotta játéktevékenységnek, így mint játéktevékenység-formát kizártuk a további vizsgálatból. A csoportosítás szerint általában szabad levegőn folynak az alábbi játékok: foci, labdázás, fáramászás, katonás játék a szabadban, bunkerépítés, csavargás, biciklizés, fogócska, bújócska, hintázás, mászókázás. Az általában zárt térben zajló játékok a következők: játékkatonákkal, játékautókkal történő játék, építőkockával, legóval való játék, babázás, videójáték, társasjáték, beszélgetés, kártyázás, rajzolás. Az egyes játékaktivitás-formák preferenciáját a vizsgálatba bevont 365 fó hétfokozatú Likerttípusú skálán az egyáltalán nem (0) és a nagymértékben (6) végpontok között értékelte. A két csoport skálaértékeinek főkomponens-analízise alapján képzett alcsoportok képezték a jelen vizsgálatunk kiindulópontját. A zárt térben és a szabadban végzett játéktevékenység főkomponens-elemzésének eredményeit az 1. és a 2. táblázat tartalmazza. 
2.2.2. Félelemfelmérő Lista (Fear Survey Schedule, FSS; Arrindell és mtsai, 2003; Arrindell, Oei, Evans, \& Van der Ende, 1991). Az 52 tételes kérdőív a mindennapok során felvetődő, félelmet kiváltó helyzetekkel kapcsolatos érzékenységet, a félelem kialakulásának okaitól független általános veszélyeztetettséget méri fel. A tételekre való válaszadás ötfokozatú Likert-típusú skálán történik az egyáltalán nem (0) és az igen nagyon (4) végpontok között. Az FSS faktorai az alábbiak: (a) szociális félelem; (b) agorafóbiás félelem; (c) betegségektől, vagy testi sérüléstől való félelem; (d) agressziót vagy szexuális jeleneteket tartalmazó helyzetektól való félelem; (e) állatoktól való félelem. A magasabb pontszám nagyobb mértékú félelmet jelez. A felmérólista hazai adaptációja a Cross-cultural Clinical Psychology Study Group tagjai (Willem A. Arrindell, Gaszner Péter és Kállai János) közremúködésével készült. Más nemzetek mellett a magyar egyetemista populációra vonatkozó átlag, szórás és Cronbach-alfa-értékek Arrindell és munkatársai (2003) publikációjában megtalálhatók. A magyar fordítás angol nyelvre történő visszafordítása után a tételek egyezését $W$. A. Arrindell ellenőrizte. A lista a szerzők engedélyével használható. A 2003-ban közölt eredeti verzió újraértékelése (és esetleges korrekciója) az elkövetkező évek fontos feladata. Éppen ezért az FSS listát ebben a tanulmányban nem tesszük közzé függelék formájában, de a levelező szerzőnél hozzáférhető.

\subsection{Adatfeldolgozás}

A játékpreferencia itemek dimenzióredukciója főkomponens-elemzéssel történt, Varimax forgatás mellett; a szabadban és a zárt helyen folytatott játékok csoportosításain külön-külön. A játékpreferenciákból és az FSS alapján képzett változók közötti kapcsolatok feltérképezése először kétmintás eljárásokkal történt. A nemek szerinti összehasonlító elemzéseket kétmintás t-próbával végeztük. A konstruktumok közötti együttjárásokat Pearson-féle korrelációs elemzéssel vizsgáltuk.

A megfigyelt nemi különbségeken felül a különböző játékaktivitásformapreferenciák predikciós értékeit a felnőttkori félelmekre hierarchikus lineáris regressziós egyenletek formájában elemeztük, regresszálva az FSS összesített, valamint öt alskáláját a játékpreferenciákból képzett változókra a nem és az életkor bevonásával.

Minden regresszió esetében először a résztvevők nemének és életkorának a hatása egyszerre lett beléptetve a modellbe, fix prediktorként („forced entry" módszerrel), majd második blokkban a játéktípusok négy változóját definiáltuk „stepwise” szelekció szerint. Így a végső modellek a nem és a kor hatásának kontrollálása után is szignifikáns játéktípusokat tartalmazták. A statisztikai analízis az IBM SPSS 24 segítségével történt. 


\section{Eredmények}

\subsection{Játék helyszínek főkomponens-analízise}

A csoportosításokon külön főkomponens-analízist végeztük, ahol a Cattell (1952) által javasolt sajátértékeket ábrázoló „scree-plot” -on mutatkozó inflexio helye és az így kapott struktúra értelmezhetőségének figyelembevétele alapján, Varimax forgatás mellett két-két orthogonális játéktípus komponenst különítettünk el (1-2. táblázat).

Az „egyszerú struktúra” elvén, a megfelelő komponenssel száliens, kiemelkedő, vagy a többi komponenshez képest a legmagasabb faktortöltéssel rendelkezó és ugyanahhoz a komponenshez tartozó tételekból négy dimenziót alakítottunk ki; amelyek a szabadban zajló test-test elleni fizikai küzdelem (SZ1), és társas kapcsolatépítés (SZ2), valamint zárt térben folytatott szerepkövetó játék (Z1) és szociális konstrukciós gyakorlatok (Z2) neveket kapták. A főkomponens-analízis releváns eredményeit és a fent leírt módon adott komponenshez tartozó tételekből (félkövérrel jelölve) létrehozott skálák megbízhatósági mutatóit az 1-2. táblázat tartalmazza.

1. táblázat. A szabadban zajló játékpreferenciákon végzett főkomponens-elemzés eredményei

\begin{tabular}{|l|c|c|}
\hline & SZ1 & SZ2 \\
\hline foci & $\mathbf{0 , 7 2}$ & $-0,19$ \\
\hline labdázás & $\mathbf{0 , 6 9}$ & 0,17 \\
\hline fáramászás & $\mathbf{0 , 6 4}$ & 0,18 \\
\hline katonás kint & $\mathbf{0 , 5 8}$ & $-0,33$ \\
\hline bunkerépítés & $\mathbf{0 , 5 2}$ & 0,32 \\
\hline csavargás a környéken & $\mathbf{0 , 4 4}$ & 0,11 \\
\hline bicikli & $\mathbf{0 , 4 2}$ & 0,23 \\
\hline hintázás & $-0,26$ & $\mathbf{0 , 7 0}$ \\
\hline mászóka & 0,16 & $\mathbf{0 , 6 5}$ \\
\hline fogócska & 0,15 & $\mathbf{0 , 5 5}$ \\
\hline bújócska & 0,17 & $\mathbf{0 , 5 1}$ \\
\hline Sajátérték & 2,64 & $\mathbf{1 , 7 3}$ \\
\hline Magyarázott variancia \% & 23,98 & 15,75 \\
\hline Cronbach a & 0,66 & 0,53 \\
\hline
\end{tabular}

Megjegyzés: $\mathrm{KMO}=0,683 ; \chi^{2}(55)=684,094 ; p<0,001$. 
2. táblázat. A zárt téri játékpreferenciákon végzett főkomponens-elemzés eredményei

\begin{tabular}{|l|r|r|}
\hline & $\mathbf{Z 1}$ & $\mathbf{Z 2}$ \\
\hline játékkatonákkal & $\mathbf{0 , 7 7}$ & $-0,10$ \\
\hline játékautókkal & $\mathbf{0 , 7 4}$ & $-0,02$ \\
\hline babázás & $\mathbf{- 0 , 6 6}$ & 0,32 \\
\hline legós építő & $\mathbf{0 , 5 1}$ & 0,47 \\
\hline videójáték & $\mathbf{0 , 4 8}$ & $-0,02$ \\
\hline társasjáték & $-0,09$ & $\mathbf{0 , 6 5}$ \\
\hline kártyázás & 0,02 & $\mathbf{0 , 6 1}$ \\
\hline beszélgetés & $-0,20$ & $\mathbf{0 , 6 0}$ \\
\hline rajzolás & $-0,12$ & $\mathbf{0 , 5 4}$ \\
\hline építókocka & 0,40 & $\mathbf{0 , 5 3}$ \\
\hline Sajátérték & $\mathbf{2 , 3 3}$ & $\mathbf{2 , 0 1}$ \\
\hline Magyarázott variancia \% & 23,29 & $\mathbf{2 0 , 1 3}$ \\
\hline Cronbach a & 0,66 & 0,54 \\
\hline
\end{tabular}

Megjegyzés: $\mathrm{KMO}=0,682 ; \chi^{2}(45)=556,869 ; p<0,001$.

\subsection{Nemi különbségek}

Eredményeink szerint a férfiak a nókhöz képest jobban kedvelik a szabadban zajló játékokat. A beltéri játékra vonatkozó összesített értékek azonban nem jeleznek szignifikáns nemi különbséget. Differenciáltabb a kép, ha a nemi különbségeket a játéktípusok vonatkozásban külön-külön is megvizsgáljuk. A játéktípusokra való visszaemlékezés során az általunk vizsgált nők a szabadban végzett játékok közül a társas kapcsolatok építésére, a beltéri játékok esetében pedig a szociális konstrukció gyakorlására leginkább alkalmas játékokat választják. A férfiak ugyanakkor a szabadban zajló fizikai küzdelmeket, és a zárt térben kivitelezhető szerepjátékokat preferálják.

Szignifikáns eltérések mutatkoznak a félelmekkel összefüggő elkerülő magatartás, a félelmeket kiváltó helyzetekkel kapcsolatos érzékenység tekintetében is, ahol a nők valamennyi skálán magasabb pontszámmal rendelkeztek. Az adatokat a 3. táblázatban részletezzük. 
3. táblázat. Leíró statisztika és a nemi különbségek eredményei

\begin{tabular}{|l|r|r|r|r|r|r|c|}
\hline \multirow{2}{*}{ Változók } & \multicolumn{2}{|c|}{ férfi } & \multicolumn{2}{c|}{ nó } & \multicolumn{2}{c|}{ teljes minta } & \multirow{2}{*}{-érték } \\
\cline { 2 - 7 } & Átlag & \multicolumn{1}{|c|}{ SD } & Átlag & SD & Átlag & \multicolumn{1}{c|}{ SD } & \\
\hline Z1. Szerepjáték & 3,92 & 0,65 & 2,68 & 0,67 & 3,13 & 0,89 & $5,85^{* * *}$ \\
\hline $\begin{array}{l}\text { Z2. Szociális } \\
\text { konstrukciós gyakorlatok }\end{array}$ & 3,56 & 0,65 & 3,86 & 0,64 & 3,75 & 0,66 & $-5,18^{* * *}$ \\
\hline Z. Összesített & 3,44 & 0,51 & 3,39 & 0,5 & 3,41 & 0,5 & $-0,12$ \\
\hline $\begin{array}{l}\text { SZ1. Test-test elleni } \\
\text { küzdelem }\end{array}$ & 3,92 & 0,64 & 3,41 & 0,73 & 3,60 & 0,74 & $6,84^{* * *}$ \\
\hline $\begin{array}{l}\text { Sz2. Társas } \\
\text { kapcsolatépítés }\end{array}$ & 3,46 & 0,73 & 3,89 & 0,63 & 3,73 & 0,70 & $-5,00^{* * *}$ \\
\hline SZ. Összesített & 3,75 & 0,54 & 3,59 & 0,57 & 3,65 & 0,56 & $3,81^{* *}$ \\
\hline I. Szociális félelem & 17,14 & 8,49 & 21,83 & 9,23 & 20,12 & 9,23 & $-4,92^{* * *}$ \\
\hline $\begin{array}{l}\text { II. Szex és agresszió } \\
\text { félelem }\end{array}$ & 7,94 & 5,01 & 9,99 & 5,16 & 9,24 & 5,19 & $-3,71^{* * *}$ \\
\hline III. Félelem állatoktól & 5,47 & 4,90 & 9,14 & 6,09 & 7,80 & 5,95 & $-6,30^{* * *}$ \\
\hline $\begin{array}{l}\text { IV. Félelem } \\
\text { betegségektól, sérüléstől }\end{array}$ & 12,37 & 8,79 & 15,02 & 10,28 & 14,05 & 9,83 & $-2,66^{*}$ \\
\hline V. Agorafóbiás félelem & 8,88 & 6,37 & 11,18 & 6,22 & 10,34 & 6,36 & $-3,35^{* * *}$ \\
\hline VI. FSS összesített & 51,80 & 26,80 & 67,20 & 28,70 & 61,60 & 29,00 & $-5,13^{* * *}$ \\
\hline
\end{tabular}

Megjegyzés: * $p<0,05 ;{ }^{* *} p<0,01 ;{ }^{* * *} p<0,001$.

\subsection{A változók közti együttjárások}

A 4. táblázat tartalmazza a Félelemfelmérő Lista és a játéktípusok skáláinak együttjárásait, valamint az interkorrelációkat. Megállapítható, hogy az FSS alskálái közepes erősségú és szignifikáns pozitív lineáris kapcsolatban állnak egymással. A két-két zárt térben és szabad levegőn zajló játéktípus között az első esetében nem található szignifikáns összefüggés, az utóbbi esetében pedig szignifikáns, pozitív irányú, de gyenge a kapcsolat.

A fizikai kihívásokon alapuló szabadtéri játék pozitív irányú, szignifikáns korrelációkat mutat a szerepkövető és konstrukciós típusokkal egyaránt, azonban míg az első együtthatója közepes erősségúnek mondható, a második igen gyenge. 


\begin{tabular}{|c|c|c|c|c|c|c|c|c|c|c|c|}
\hline$\dot{x}$ & $\begin{array}{l}\text { Ò } \\
\text { Oे } \\
\text { ' }\end{array}$ & $\begin{array}{l}\text { S } \\
\text { o } \\
\text { i }\end{array}$ & $\begin{array}{l}5 \\
0 \\
\end{array}$ & 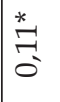 & $\begin{array}{l}2 \\
0 \\
0 \\
1\end{array}$ & $\begin{array}{l}\sigma \\
\delta \\
O \\
0\end{array}$ & $\stackrel{*}{*}$ & $\begin{array}{l}3 \\
0 \\
0\end{array}$ & Oి & $\begin{array}{l}*^{*} \\
\stackrel{7}{7} \\
1\end{array}$ & 1 \\
\hline$\dot{x}$ & $\begin{array}{l}1 \\
0 \\
0 \\
1\end{array}$ & $\begin{array}{l}8 \\
8 \\
0\end{array}$ & $\begin{array}{l}+ \\
0 \\
0\end{array}$ & $\begin{array}{l}0 \\
0 \\
0 \\
0\end{array}$ & $\begin{array}{l}8 \\
0 \\
0 \\
1\end{array}$ & $\begin{array}{l}0 \\
0 \\
0 \\
1 \\
1\end{array}$ & $\begin{array}{l}\text { * } \\
\stackrel{*}{*} \\
\stackrel{2}{0} \\
\\
1\end{array}$ & $\begin{array}{l}\text { 炎 } \\
\text { 今̃ } \\
\text { ○े }\end{array}$ & 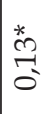 & 1 & \\
\hline xִ & 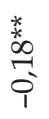 & \begin{tabular}{l} 
* \\
\multirow{2}{*}{} \\
$\stackrel{2}{0}$ \\
i
\end{tabular} & 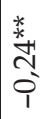 & $\begin{array}{l}\text { * } \\
\stackrel{2}{*} \\
\stackrel{2}{0} \\
0 \\
1\end{array}$ & 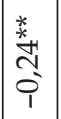 & 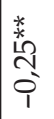 & $\begin{array}{l}\text { * } \\
\text { *o } \\
\text { + } \\
0\end{array}$ & $\stackrel{*}{*}$ & 1 & & \\
\hline$\stackrel{\Xi}{\Xi}$ & $\begin{array}{l}\tilde{0} \\
0 \\
0\end{array}$ & $\begin{array}{l}\circ \\
\stackrel{1}{\circ} \\
\circ\end{array}$ & $\begin{array}{l}\circ \\
\stackrel{-}{\circ}\end{array}$ & 今o & $\begin{array}{l}5 \\
0 \\
0 \\
1\end{array}$ & 노 & 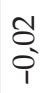 & 1 & & & \\
\hline$\stackrel{\Xi}{>}$ & 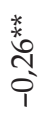 & 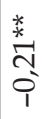 & 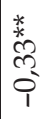 & 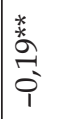 & 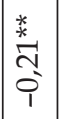 & \begin{tabular}{l}
$*$ \\
\multirow{2}{*}{} \\
$\infty$ \\
0 \\
0 \\
1
\end{tabular} & 1 & & & & \\
\hline$\dot{>}$ & $\begin{array}{l}\text { * } \\
\text { ª } \\
0 \\
0 \\
0\end{array}$ & $\begin{array}{l}* \\
* \\
\infty \\
\infty \\
0\end{array}$ & $\begin{array}{l}\text { * } \\
\stackrel{*}{*} \\
\stackrel{2}{0}\end{array}$ & $\begin{array}{l}* \\
* \\
\infty \\
\infty \\
0 \\
0\end{array}$ & 菜 & 1 & & & & & \\
\hline$\vec{b}$ & 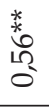 & 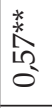 & 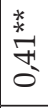 & 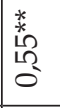 & 1 & & & & & & \\
\hline$z$ & 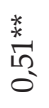 & 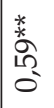 & 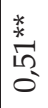 & 1 & & & & & & & \\
\hline ヨ & $\begin{array}{l}\text { * } \\
\stackrel{*}{\sharp} \\
0\end{array}$ & 莡 & 1 & & & & & & & & \\
\hline ઘ & $\begin{array}{l}\text { * } \\
\stackrel{*}{*} \\
0^{\prime}\end{array}$ & 1 & & & & & & & & & \\
\hline$-\dot{ }$ & 1 & & & & & & & & & & \\
\hline & 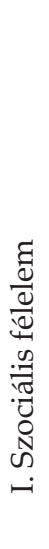 & 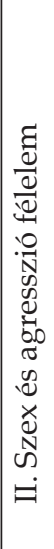 & 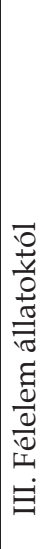 & 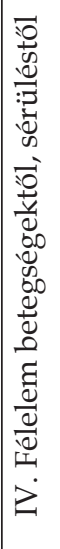 & 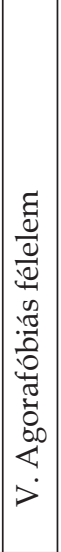 & 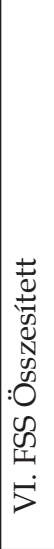 & 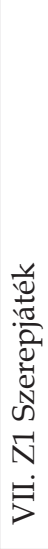 & 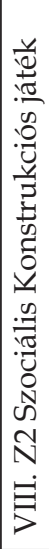 & 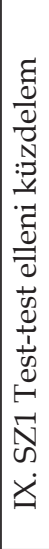 & 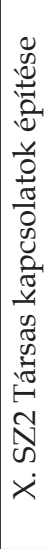 & $\begin{array}{l}\frac{\tilde{0}}{0} \\
\frac{\vec{y}}{\vec{u}} \\
\dot{\vec{x}}\end{array}$ \\
\hline
\end{tabular}


A társas kapcsolatok gyakorlása együtthatója szintén gyenge, de szignifikáns pozitív kapcsolatban áll a szociális konstrukciós játék preferenciával, és szignifikáns, negatív, de gyenge korrelációt mutat a szerepkövetést igénylő játékokkal.

A félelem és a játékpreferenciák összefüggéseit tekintve kizárólag a szerep- és szabálykövetést, valamint a fizikai kihívásokat igénylő játékok esetében lelhetők fel szignifikáns, negatív irányú korrelációk, amelyek az állatoktól való félelem és a szerepjáték között mutatkozó mérsékelt erősségú kapcsolattól eltekintve gyengék.

\subsection{A regresszióanalízis eredményei}

A félelem és a játékpreferencia kapcsolatát többszörös lineáris regresszió elemzéssel teszteltük a nem és az életkor kontrollja mellett. Eredményeinket összefoglalva elmondható, hogy bár a megmagyarázott varianciát tekintve az értékek alacsonynak mondhatók, valamennyi FSS skála esetében azonosítható olyan játékfajta, amely a nem és az életkor hatásán túl is szignifikánsan hozzájárul a gyermekkori játék felnőttkori félelemekkel való kapcsolatának megértéséhez. A vizsgált játékfajták közül egyedül a szociális konstrukciós játék nem jelent meg egyetlen modellben sem szignifikáns független változóként. A korrelációs elemzések eredményei alapján az előzetes elvárásokkal egyezően minden esetben negatív irányú a kapcsolat, ami arra utal, hogy adott játéktípus preferenciája és annak valószínúsíthető fokozottabb gyakorlása a megfelelő félelem skálák pontszámának alacsonyabb értékeivel jár együtt. A szabadban zajló fizikailag küzdelmes játékok és a zárt térben zajló szerepgyakorló játékok határozott preferenciája és az alacsony félelem pontszámok együtt járnak. A regresszióanalízisek eredményeit az 5. táblázat foglalja össze.

A szerepgyakorló játékok emelkedett preferenciája a szociális, a szexuális és agresszív jeleneteket tartalmazó, az állatokkal és a betegségekkel kapcsolatos félelmek esetében egyaránt alacsonyabb szinteket jelez előre. Kiemelendő továbbá, hogy a betegségtől való félelem a magasabb életkorhoz kapcsolódik. Ugyanakkor a betegségtól való félelem alacsony értékei a zárt helyeken folytatott szerepjátékok és gyakorlatok erősebb preferenciájával járnak együtt.

Az állatoktól való félelem esetében jelentkezik a korábban megfigyelt szignifikáns nemi diszkrepancia. A szociális félelmeknél azonban ez a hatás csak tendencia szintú, a szexuális jelenetektől és agressziótól, valamint a betegségektől és sérülésektől való félelem esetében pedig nem mutatkozik szignifikáns nemi különbség. 


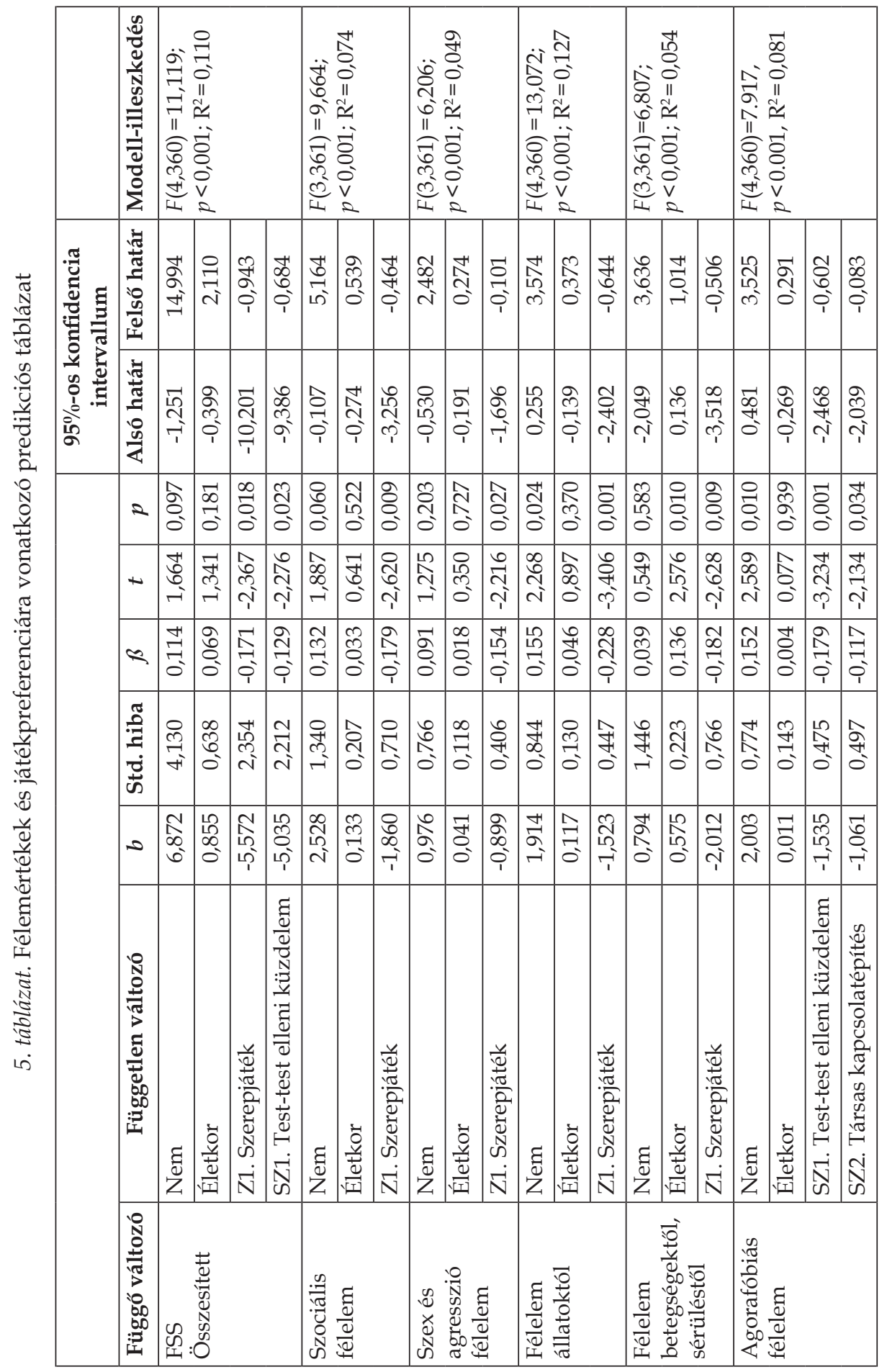


Agorafóbiás félelmek tekintetében már eltérő képet találunk: a szabadban zajló test-test elleni küzdelemben és a társas kapcsolatok építésben szerzett tapasztalatok a meghatározók, amelyek alacsony agorafóbiás értékekkel járnak együtt. A nem ezúttal is szignifikáns magyarázóerővel bír e félelemfajtára nézve: a nóknél magasabb, mint a férfiaknál.

Az összesített FSS skálát nézve, a félelmek globális alakulásában a beltéri szerepkövetést és a kültéri test-test elleni küzdelmet igénylő játékok gyakorlására való igény jelenik meg meghatározó tényezóként.

\section{Diszkusszió}

\subsection{Játékhelyszín szerinti csoportosítás}

A rendelkezésünkre álló játékaktivitás formákat szakértői csoport közremúködésével beltéri és szabadban zajló játéktevékenységre osztottuk, amelyeken belül főkomponens-elemzéssel 2-2 megbízható játékaktivitás típust különítettünk el. Eredményeink szerint a felidézett játék helyszínek és preferenciák jelentős nemi különbségeket mutatnak. Férfiak a nőkkel szemben gyermekkori emlékeikról adott beszámolójuk során erősebb szabadban végzett játékpreferenciáról számoltak be. Zárt térben zajló játékpreferencia értékekben azonban nemi különbség nem mutatkozott. Ezek az eredmények részben megerősítik a játékszínhely választásával kapcsolatos korábbi elképzelést, amely szerint a fiúk az otthontól távoli játék színhelyeket kedvelik (Edwards, Knoche, \& Kumru, 2001; Martin és mtsai, 2013; Pellegrini, 2009). Ugyanakkor árnyalja a képet, hogy a játékaktivitás típusa szerint lányok és fiúk különböző játéktípusokat részesítenek előnyben. Lányok számára a szabadban zajló játék elsősorban a csapatépítésről, kapcsolatok kialakításról és fenntartásáról, a közös játék örömének fokozásáról szól; zárt térben pedig a nagyobb összpontosítást és türelmet, feladattudatot és a rejtvények megfejtésének igénye által táplált kíváncsiságot igénylő játékokat preferálják. A fiúk ezzel szemben a szabadban, a fizikai kihívásokkal és küzdelemmel járó, fokozott fizikai erőfeszítést igénylő játékokban vesznek részt szívesebben, a zárt térben rendelkezésre álló repertoárból pedig inkább a szerepek gyakorlására alkalmas játékokat választják.

\subsection{Játéktípus és félelem}

A játék során felhalmozott tapasztalatok - más meghatározó tényezők mellett - a felnőttkori kapcsolatok kiépítésével, a tapasztalatszerzés módszereivel, a mindennapi fizikai és szociális adaptációval mutatnak összefüggést 
(Hendricks, 2015; Piaget, 1962). Jelen vizsgálatunkban az adaptációt befolyásoló tényezők sorából a félelemmel kapcsolatos érzékenységet emeltük ki. Adataink más vizsgálatok eredményeivel összhangban mutatják, hogy a felnőtt nők nagyobb érzékenységet mutatnak a félelmet mobilizáló helyzetekben (Arrindell, Emmelkamp \& Ende, 1984; Arrindell és mtsai, 2003). Az alkalmazott félelmi lista valamennyi skáláján - a betegségtől és fizikai sérüléstól való félelmet kivéve - a nők lényegesen magasabb értékeket mutattak, mint a férfiak. Az életkor és a nem kontrollja mellett végzett lineáris regresszió elemzés eredménye szerint az összesített félelemmutató alacsony értékei a zárt térben zajló szerepjátékok és a szabadban folytatott fizikai kihívásokat igénylő játékaktivitások erőteljesebb preferenciájával járnak együtt. A félelemfaktorok részletesebb elemzésének eredménye szerint az alacsony szociális félelem, a szexuális vagy agresszív jelenetektől való félelem, állatoktól, betegségtól, illetve fizikai sérüléstől való félelem a zárt helyen zajló szerep- és szabályjátékok preferenciájával mutat kapcsolatot. Az agorafóbiára vonatkozó érzékenység ezektől eltérő játékaktivitás mintázattal mutat összefüggést. Alacsony agorafóbiás szorongás a szabadban végzett játéktevékenységgel (test-test elleni küzdelem, társas kapcsolatépítés) függ össze. Megállapítható tehát, hogy a félelem különböző típusaira vonatkozó érzékenység azoknál a személyeknél alacsonyabb, akik gyermekkorukra visszaemlékezve a zárt térben zajló szerep- és szabályjátékokat kedvelték a leginkább. Az agorafóbia alacsony értékei azonban a szabadban végzett játéktevékenység preferenciájához kötődnek.

Jelen vizsgálat keretei között a gyermekkorra való visszaemlékezés alapján zárt helyen vagy a szabadban zajló játékokkal kapcsolatos személyes preferenciákat vetettük össze a személy felnőttkori félelmeinek mértékével és típusával. A szabadban végzett játék közben szerzett szociális, motoros és navigációs tapasztalatok szerepet játszanak a félelmek iránti fogékonyság csökkenésében. E tekintetben elsősorban az agorafóbia és a szabad környezetben folytatott játéktevékenység kölcsönhatásait tárgyaló kognitív és viselkedésterápiás fejlődésmodellből indultunk ki (Guidano \& Liotti, 1983; Jacobs \& Nadel, 1985). A vesztibulomotoros és navigációs tapasztalatok jelentős védelmet biztosítanak az alapvetően szeparációs szorongásra visszavezethető agorafóbiás ingerekkel kapcsolatos érzékenység növekedésével szemben. Agorafóbiás személyek rehabilitációs programjai kiemelt szerepet tulajdonítanak a játékos, szabadban és zárt térben egyaránt végezhető felderítő, hely- és irányváltásokkal tarkított mozgásos gyakorlatoknak. A gyakorlatok további kiemelt elemei a közös tevékenység, a társak bátorító jelenléte, és a megfelelő figyelem-allokációk elsajátítása (Jacob és mtsai, 2001).

A hely nemcsak objektív, hanem dinamikusan változó fogalom is, amelynek jelentése a gyermekek környezettel való kapcsolata folyamatában ala- 
kul ki (Gibson, 1979; Matthews, 2000). Amennyiben a helyet birtokba vevő játéktevékenység során a gyermekek sok gátló tényezővel találkoznak (túlzott szülői támogatás, fokozott tiltások, a környezet sivársága, vagy a túl erős közlekedési forgalom), csökken a környezet iránti érdeklődés és mindez megzavarhatja a környezet felett érzett kompetencia kialakulását. A gyermek a térrel való tranzakciók folyamatában, az affordanciákat és a környezet minőségi lehetőségeit figyelembe véve alakítja ki a térhez, és a természetes és az épített környezethez való viszonyát sajátítja el, illetve érti meg annak törvényszerúségeit, korlátait és lehetőségeit (Moore, 1986). Eredményeink rámutatnak arra, hogy ennek a megértési folyamatnak az egyik következménye lehet az utazással; a tömegrendezvényeken való részvétellel; a nagy, határoló területekkel nem rendelkező vagy éppen menekülésre lehetóséget nem kínáló zárt terekkel kapcsolatos félelem, amelyben a személy úgy érzi, nem kap megfeleló támogatást, nincsenek társai az agorafóbiás szorongásait kiváltó helyzetek legyőzésében. Az adaptáció említett hiányossága részben az itt részletesen nem tárgyalt autonómiahiányból és szeparációs szorongásból származtatható, amely a gyermeki fejlődés kezdeti időszakától már érzékennyé teszi a személyt a saját felelősségén nyugvó döntések meghozatalára, az önálló életvitel kialakításra (Bowlby, 1973; de Ruiter \& van Ijzendoorn, 1992; Holmes, 2008). Jelen tanulmányunk célja elsősorban a környezet, a játékaktivitás és a félelem összefüggéseinek tanulmányozása.

A környezetpszichológiai nézőpont, a félelmek legyőzésében a szabadban végzett játéknak kitüntetett szerepet szán. A játéktér felderítése az eltávolodás, a megközelítés és visszatérés társas rítusai a döntési stratégiák fejlődésének kiindulópontjai (Heft, 1998; Moore, 1986). A független, szabadban zajló játék olyan gyermekkori tapasztalatokat nyújthat, amelyek fejlesztik a felnőttkori téri tájékozódási képességeket és a biztonságos területektől eltávolodva is biztonságérzést kelthetnek. A független mobilitás empirikus vizsgálatok során kialakított modellje a játékos explorációban, a navigációs tapasztalatok megszerzésében, a biztonságot adó személytől való eltávolodás és hozzá való visszatérés dianmikájában látja a kötődés igazi természetét (Ainsworth és mtsai, 1978). A kompetenciák fejlődésével az exploráció ideje és távolsága fokozatosan növekszik. A kognitív képességek mellett a szociális kompetencia a környezettel és a szülői neveléssel interakcióban befolyásolják a környezet explorációját és bizonyos játéktevékenységek preferenciáját (Lee és mtsai, 2015). Szembe kell azonban néznünk azzal a ténnyel, hogy a korábbi évekhez képest napjainkban már vidéki településeken is csökken a gyermekek szabadban zajló játékaktivitása. Nemcsak a szülők korlátozzák a gyermekeket (Karsten, 2005), hanem a közlekedési és népességi körülmények kényszerítő hatásai is. A gyermekek részéről gyakori igény, hogy a szülők játszanak velük. A biztonsággal és felügyelettel kap- 
csolatos problémát a gyermekek nagyobb és szervezettebb, az esetek többségében formális csoportokba integrálásával kívánják megoldani. Ilyen körülmények között az ellenőrzés, a szülők elérésének lehetősége elősegíti ugyan a játék kibontakozását, de ugyanakkor hátráltatja is az autonómia és egyes szociális kompetenciák fejlődését (Herrington \& Brussoni, 2015; Herrington és mtsai, 2007). Adataink erre a tényre is ráirányítják a figyelmet. A biztonság hiánya esetén a gyermekek többször kapnak szülói kíséretet. Ezt a protekciós kényszert a legtöbb esetben a környezet bizonytalansága, a zsúfoltság, a búnesetek számának növekedése indokolja (Blakely, 1994), amely önmagában is olyan viselkedési stratégiákat alakít ki, amely növeli a félénkséget, érzékenyebbé teszi a gyermekeket a veszélyekkel szemben. Mások által veszélytelennek tartott helyzetek így „veszélyes” minősítést kaphatnak (Prezza és mtsai, 2001).

A biztonságos környezet által kínált, szabadban zajló felszabadult játék hozzájárul a félelmek - különösen az agorafóbiás aggodalmakra való veszélyeztetettség - csillapításához. A kérdés az, hogy milyen körülmények és környezeti feltételek azok, amelyek e téren a gyermekek és a felnőttek számára egyaránt növelik az adaptációs képességet. A probléma egyik lehetséges megoldása a szomszédsági közösségi események gyakoriságának a növelése, ahol a szülők is részt vehetnek és ismerkedhetnek egymással. A játék színterének közös felelősségre épülő szemmel tartása a közösségi összefogást is facilitálja. Ennek megvalósításához viszont megfelelő építészeti és környezetpszichológiai keretek szükségesek. A közösen bejárt terület megismerése csökkenti a szülók aggodalmát, társakat találnak a kontrollhoz, erősítik az otthonosságot és a birtokban tartást (Hart \& Parkhurst, 2011). Az ilyen körülmények között szerzett tapasztalatok csökkentik az agorafóbiás és az állatokhoz kapcsolódó félelmek iránti veszélyeztetettséget. A szülők részéról kiadott mobilitási engedély érvényességi köre megnő, így a tapasztalatszerzés köre kibővül (Hüttenmoser \& Meierhofer, 1995).

Összegzésül: a jelen vizsgálatunk eredménye szerint a szabad, veszélyekkel is dacoló, gyors hely- és helyzetváltoztatással járó, testi sérüléseket is kockáztató játékhelyzetek bizonyos értelemben korlátozzák a félelmek és a fóbiák kibontakozását. Mindennek előfeltételét képezi a megfelelő környezeti adottságok kiaknázása, az adott helyre vonatkozó mentális térképben elraktározott ismeretek megszilárdítása. Eredményeink összhangban vannak azokkal a megállapításokkal, miszerint az alacsonyabb játékpreferencia értékekkel rendelkezők felnőttkorukban kevésbé szociálisak, félelmek kialakulására való esékenységük nagyobb (Fisher, 1992; McArdle, 2001). Játéktípus és játéktárgy megválasztás tekintetében biológiailag meghatározott játékpreferencia különbségek mutatkoznak (Servin \& Nordenstörm, 2003). Adataink egyértelmúen alátámasztják, hogy a biológia nem meghatározó a játékpreferencia alakulásának vonatkozásában. Fiúk és lányok, férfiak és 
nők játékreprezentációinak vizsgálata egyértelmúen alátámasztotta ezt a tételt (Alexander \& Hines, 2002). A játékpreferencia különbségei a játék színhelye és a játék típusa vonatkozásában egyaránt megmutatkoznak. A játéktípus és -helyszín preferenciája a félelmekre vonatkozó érzékenységgel öszszefüggést mutat.

\section{Limitációk}

A vizsgálat a felépítéséből adódóan nem ad választ arra kérdésre, hogy a játékpreferencia típusa és a félelmek kapcsolatát mennyiben befolyásolják a személyek temperamentum-sajátosságai, a szülők gyermeknevelési szokásai, a szülők által kínált biztonságos háttér megléte vagy hiánya, a közvetlen életfeltételek, a városi vagy falusi környezet, valamint a genetikai, illetve a gender hatások. Ezekre a kérdésekre a játékpreferenciák és a mindennapi felnőtt aktivitásformák kapcsolatának mélyebb megértése után kereshetjük a válaszokat. Ezekhez szükséges módszertani eszközök, a család által kínált biztonság, temperamentum és a szülői nevelési szokások mérésére alkalmas eszközök már hazai használatban is rendelkezésre állnak, amelyek elősegíthetik a játékfolyamat és a felnőttkori viselkedés és párkapcsolati viszonyok alakulásának alaposabb megértését.

\section{Irodalom}

Ainsworth, M., Blehar, M., Waters, E., \& Wall, S. (1978). Patterns of attachment. Hillsdale, NJ: Erlbaum

Alexander, G. M., \& Hines, M. (2002). Sex difference in response to children's toys in nonhuman primates. Evolution and Human Behavior, 23(6), 467-479.

Arrindell, W.A., Eisemann, M., Richter, J., Oei, T.P., Caballo, V.E., van der Ende, J., et al. (2003). Masculinity-feminity as a national characteristic and its relationship with national agoraphobic fear levels: Fodor's sex role hypothesis revitalized. Behaviour Research and Therapy, 41(7), 795-807.

Arrindell, W.A., Emmelkamp, P.M.G., \& van der Ende, J. (1984). Phobic dimension: I. Reliability and generalizability across samples, gender and nations. Advances in Behavioral Research and Therapy, 6, 207-254.

Arrindell, W.A., Oei, T.P.S, Evans, L., Van der Ende, J. (1991). Agoraphobic, animal, deathinjury-illness and social stimuli clusters as major elements in a four dimensional taxonomy of self-rated fears: first-order level confirmatory evidence from Australian sample of anxiety disorder patients. Advances in Behaviour Research and Therapy, 13(4), 227-249.

Barcsi, B., Hollódy, K., Péley, B., Dorn, K., Kerns, K.A., Rózsa, S., et al. (2017). Security, reliance and availability: Psychometric features of the Kerns' Security Scale in Hungarian population. Mentálhigiéné és Pszichoszomatika, 18(1), 171-193.

Blakely, K. (1994). Parents' conceptions of social dangers to children in the urban environment. Children's Environments, 11(1), 16-25. 
Bowlby, J. (1973). Separation: Anxiety and Anger. Vol II. Attachment and Loss. New York: Basic Books

Carver, A., Timperio, A., \& Crawford D. (2008). Perceptions of Neighborhood Safety and Physical Activity among Youth: The CLAN Study. Journal of Physical Activity and Health, 5(3), 430-444.

Cashdan, E., Kramer, K.L., Davis, H.E., Padilla, L., \& Graves, R.D. (2016). Mobility and navigation among the Yucatec Maya: Sex differences reflect parental investment, not mating competition. Human Nature, 27(1), 35-50.

Cattell, R.B. (1952). Factor analysis. New York: Harper

Chawla, L. (1992). Childhood place attachment. In I. Altman, \& S.M. Low, Place attachment (63-87). New York: Plenum Press

Clements, R. (2004). An investigation of the status of outdoor play. Contemporary Issues in Early Childhood, 5(1), 68-80.

Corbishley, P. (1995). A parish listens to its children. Children's Environments, 12(4), 414-426.

Cosco, N.G., Moore, R.C. \& Islam, M.Z. (2010). Behavior mapping: A method for linking preschool physical activity and outdoor design. Medicine and Science in Sports and Exercise, 42(3), 313-519.

de Ruiter, C., \& van Ijzendoorn, M.H. (1992). Agoraphovia and anxious-ambivalent attachment: An integrative review. Journal of Anxiety Disorders, 6(4), 365-381.

Dúll, A. (2010). Helyek, tárgyak, viselkedés. Környezetpszichológiai tanulmányok. L’Harmattan Kiadó.

Edwards, C.P. (2000). Children's play in cross-cultural perspective: A new look the Six Cultures study. Cross-Cultural Research, 34(4), 318-338.

Edwards, C.P., Knoche, L., Kumru, A. (2001). Play patterns and gender. In J. Worrell (Ed.), Encyclopedia of women and gender (809-815). San Diego: Academic Press

Fisher, E.P. (1992). The impact of play on development: A meta-analysis. Play and Culture, $5(2), 159-181$.

Frances, A., \& Dunn, P. (1975). The attachment autonomy conflict in agoraphobia. International Journal of Psychoanalysis, 56(4), 435-439.

Gelenn, N.M., Knight, C.J., Holt, N.L., \& Spence, J.C. (2012). Mraning of play among children. Childhood, 20(2), 185-199.

Gibson, J.J. (1979). The ecological approach to visual perception. Boston: Houghton-Mifflin

Guidano, V.F., \& Liotti, G. (1983). Cognitive processes and emotional disorders. New York: Guildford Press

Hámori, E. (2015). A kötődéselmélet perspektívái. A klasszikusoktól napjainkig. Budapest: Animula Kiadó

Harker, C. (2005). Playing and affective time-space. Children's Geographies, 3(1), 47-62.

Hart, J. \& Parkhurst, G. (2011). Driven to excess: Impacts of motor vehicles on the quality of life of residents of three streets in Bristol UK. World Transport, Policy and Practice, 17(2), 12-30.

Heft, H. (1998). Affordances of children's environments: a functional approach to environmental description. Children's Environments Quarterly, 5(3), 29-37.

Hendricks, T.S. (2015). Play as self-realization - toward a general theory of play. In J.E. Johson, S.G. Eberle, T.S. Hendricks, \& D. Kuscher (Eds.), The handbook of the study of play. Vol. II. (1-24). London: Rowman \& Littlefield

Herrington, S., Lesmeister, C., Nicholls, J., \& Stefiuk, K. (2007). An informational guide to young children's outdoor play spaces. Vancouver: Consortium for Health, Intervention, Learning and Development (CHILD) Letöltve: 2017.12.30-án: http://www.wstcoast. org/playspaces/outsidecriteria/7Cs.pdf 
Herrington, S. \& Brussoni, M. (2015). Beyond physical activity: the importance of play and nature-based play spaces for children's health and development. Current Obesity Report, $4(4), 477-483$.

Holmes, J. (2008). Space and the secure base in agoraphobia: A qualitative survey. Area, 40(3), 375-382.

Holt, N.L., Neely, K.C., Spence, J.C., Carson, V., Pynn, S.R., Boyd, K.A., et al. (2016). An intergenerational study of perceptions of changes in active free play among families from rural areas of Western Canada. BMC Public Health, 16:829. Doi: 10.1186/s12889016-3490-2

Hüttenmoser, M., \& Meierhofer, M. (1995). Children and their living surroundings for the everyday life and development of children. Children's Environments, 12(4), 1-17.

Hüttenmoser, M., \& Degen-Zimmermann, D. (1995). Lebensraume für. Kinder (Living Space for Children). National research programme. Cities and Transport No 70. Zürich: Marie Meierhofer-Institut für das Kind

Jacob, R.G., Whitney, S.L., Detweiler-Shostak, G., \& Furman, J.M. (2001). Vestibular rehabilitation for patients with agoraphobia and vestibular dysfunction: a pilot study. Journal of Anxiety Disord, 15(1-2), 131-146.

Jacobs, W.J., \& Nadel, L. (1985). Stress-induced recovery of fears and phobias. Psychological Review, 92(4), 512-531.

Kállai, J., Karádi, K., \& Tényi, T. (1998). A térélmény kultúrtörténete és pszichopatológiája. Budapest: Tertia Kiadó

Kállai, J., Kerekes, Zs., Osváth, A., Makány, T., \& Járai, R. (2003). Gyermekkori navigáció nemi különbségei: szorongás, félelem és navigációs stratégiák. Magyar Pszichológiai Szemle, 58(3), 319-340.

Kállai, J. (2013). A társas kapcsolatok neuropszichológiája. Budapest: Medicina Könyvkiadó Zrt.

Karsten, L. (2005). It all used to be better? Different generations on continuity and change in urban children's daily use of space. Children's Geographies, 3(3), 275-290.

Kerns, K.A., Tomich, P.L., \& Kim, P. (2006). Normative trends in perception of availability and utilization of attachment figures in middle childhood. Social Development, 15(1), $1-22$.

King, A.L.S., Valença, A.M., \& Nardi, A.E. (2010). Nomophobia: the mobile phone in panic disorder with agoraphobia: reducing phobias or worsening of dependence? Cognitive and Behavioral Neurology, 23(1), 52-54.

Kong, L. (2000) Nature's dangers, nature's pleasures: Urban children and the natural world. In S.L. Holloway, \& G. Valentine (Eds.), Children's geographies: Playing, living, learning (257-271). London: Routledge

Kruger, D., \& Byker, D. (2009). Evolved foraging psychology underlies sex differences in shopping experiences and behaviors. Journal of Social, Evolutionary, and Cultural Psychology, $3(4), 328-342$.

Kyttä, M. (2003). Children in outdoor context. Affordances and independent mobility in the assessment of environmental child friendliness. Helsinki: Helsinki University of Technology

Kyttä, M. (2006). Environmental Child-friendliness in the light of the Bullerby Model. In C. Spencer, \& M. Blades, Children and their environments. Learning, using and designing spaces (141-158). Cambridge: Cambridge University Press

Lalli, M. (1992). Urban related identity: theory, measurement and empirical findings. Journal of Environmental Psychology, 12(4), 285-303.

Lawton, C.A., \& Kállai J. (2002). Gender differences in wayfinding strategies and anxiety about wayfinding: A cross-cultural comparison. Sex Roles, 47(9), 389-401. 
Lee, H., Tamminen, K.A., Clark, A.M., Slater, L., Spence, J.C., \& Holt, N.L. (2015). A metastudy of qualitative research examining determinants of children's independent active free play. International Journal of Behavioral Nutrition and Physical Activity, 12:5. Doi: 10.1186/s12966-015-0165-9

Lepp, A., Barkley, J.E., Karpinski, A.C. (2014). The relationship between cell phone use, academic performance, anxiety, and satisfaction with life in college students. Computers in Human Behavior, 31(31), 343-350.

Lester, S., \& Maudsley, M. (2007). Play, naturally: A review of children's natural play. London: National Children's Bureau

Marks, I. (1987). Fears, phobias and rituals. Oxford: Oxford University Press

Martin, C.L., Kornienko, O., Schaefer, D.R., Hanish, L.D., Fabes, R.A., \& Goble, P. (2013). The role of sex and gender-typed activities in young children's peer affiliative networks: A longitudinal analysis of selection and influence. Child Development, 84(3), 921-937.

Matthews, H., Taylor, M., Sherwood, K., Tucker, F., \& Limb, M. (2000). Growing-up in the countryside: Children and the rural idyll. Journal of Rural Studies, 16(2), 141-153.

Matthews, M.H. (1986). Gender, graphical, and geography. Educational Review, 38(3), 259271.

McArdle, P. (2001). Children's play. Child: Care. Healthy \& Development, 27(6), 509-514.

Mérei, F., \& V. Binét, Á. (2006). Gyermeklélektan. Budapest: Medicina Kiadó

Moore, R. (1986). Childhood's domain. Play and place in child development. London: Croom Helm

Newson, J., \& Newson, E. (1987). Family and sex roles in middle childhood. In D.J. Hargraves, \& A.M. Colley (Eds), The psychology of sex roles (142-158). Cambridge: Hemisphere Publishing

Noyes, R., \& Hoehm-Saric, R. (1998). The Anxiety Disorders. Cambridge: Cambridge University Press

Pellegrini, A.D. (2009). The role of play in human development. New York: Oxford University Press

Piaget, J. (1962). Play, dreams and imitations in childhood. New York: W.W. Norton

Prezza, M. (2007). Children's independent mobility. A review of recent Italian literature. Children Youth and Environments, 17(4), 293-318.

Prezza, M., Amici, M., Roberti, T., \& Tedeschi, G. (2001). Sense of community referred to the whole town: Its relations with neighboring, loneliness, life satisfaction, and area of residence. Journal of Community Psychology, 29(1), 29-52.

Proshansky, H.M., Fabian, A.K., \& Kaminoff, R. (1983). Place identity: physical world socialization of the self. Journal of Environmental Psychology, 3(1), 57-83.

Pyle, R.M. (2002). Eden in a vacant lot: Special places, species, and kids in the neighborhood of life. In P.H. Kahn, \& S.R. Kellert, Children and nature. Psychological, sociocultural, and evolutionary investigations (305-328). Cambridge: The MIT Press

Relph, E. (1976). Place and placelessness. London: Pion

Rissotto, A., \& Tonucci, F. (2002). Freedom of movement and environmental knowledge in elementary school children. Journal of Environmental Psychology, 22(1), 65-77.

Roberts, J.A., Yaya, L.H.P., \& Manolis, C. (2014). The invisible addiction: Cell-phone activities and addiction among male and female college students. Journal of Behavioral Addictions, 3(4), 254-265.

Servin, A., Nordenstörm, A., Larson, A., \& Bohlin, G. (2003). Prenatal androgenes and gender type behavior: a study of girls with middle and severe forms of congenital adrenal hyperplasia. Developmental Psychology, 39(3), 440-450. 
Smilansky, S. (1968). The effects of sociodramatic play on disadvantage preschool children. New York: Wiley

Spencer, K., \& Wright, P. (2014). Quality outdoor play spaces for young children. Young Child, 69(5), 28-34.

Török, I.A., Bálint, A., Németh, R., Dékány, M., Pajor, K., Feldmann, Á., et al. (2010). Differences in the sexes, and the interactions of object-relations in the orientation strategy of adulthood. Kalokagathia, 48(2-3), 140-151.

Török, I.A., Rózsa, S., Hupuczi, E., Vincze, G., \& Kállai, J. (elbírálás alatt). Gyermekkori játékokra való visszaemlékezés során feltárt játéktípusok nemi megoszlása és kölcsönhatásai: Eltávolodás és visszatérés. Magyar Pszichológiai Szemle

Valentine, G.B. \& McKendirck, J. (1997). Children's outdoor play: Exploring parental concerns about children's safety and the changing nature of childhood. Geoforum, 28(2), 219-235.

Vigotszkij, L.Sz. (1971). A magasabb pszichikus funkciók fejlődése. Budapest: Gondolat Kiadó Wallon, H. (1971). Válogatott tanulmányok. Budapest: Gondolat Kiadó

Zahra, Z. (2016). The woods is a more free space for children to be creative; their imagination kind of sparks out there': exploring young children's cognitive play opportunities in natural, manufactured and mixed outdoor preschool zones. Journal of Adventure Education and Outdoor Learning, 16(2), 172-189.

\section{Köszönetnyilvánítás}

A tanulmány elkészítését a NKFI K-120334 pályázat támogatta. Jelen tudományos közleményt a szerzők a Pécsi Tudományegyetem alapításának 650. évfordulója emlékének szentelik.

\section{Szerzői munkamegosztás}

Kállai János: az elméleti háttér megteremtése, a tanulmány szerkesztése, a vizsgálat és az adatkezelés ellenőrzése. Rózsa Sándor: szerkesztés, statisztikai tervezés, adatellenőrzés. Hupuczi Ernő: statisztikai analízisek lefolytatása, az eredményközlés szerkesztése. Martin László: adatszolgáltatás, a tanulmány szerkesztése. Vincze Gábor: adatszolgáltatás, technikai kivitelezés. Lénárd Katalin: a szöveg ellenőrzése, szerkesztés, irodalmi háttérelemzés. Török Imre: adatgyújtés vizsgálatszervezés, adatbázisgondozás, tanulmányszerkesztés.

\section{Nyilatkozat érdekütközésról}

A szerzők kijelentik, hogy esetükben érdekütközések nem állnak fenn. 


\title{
Adulthood fears and childhood play type preference: indoor and outdoor
}

\author{
KÁLLAI, JÁNOS - RÓZSA, SÁNDOR - HUPUCZI, ERNŐ - \\ MARTIN, LÁSZLÓ - VINCZE, GÁBOR - LÉNÁRD, KATALIN - \\ TÖRÖK, IMRE ANDRÁS
}

Theoretical background: Early studies on spatial orientation have revealed that competencies acquired during outdoor play reduce fearful reactions shown in unexplored environments both in childhood and in adulthood. However, the cultural diversity of play activites and the problems of carrying out longitudinal studies pose difficulties to studying the relationship between childhood play and fears in adulthood. Method: The present study focused on the relationship of the types and intensity of adult participants' fears with the preferred childhood play types and environments they recalled. Participants were 365 male and female university students. 21 types of indoor and outdoor play identified in a previous study were sorted on a statistical basis into distinct groups according to playing environment. Results: The study has revealed that the two major types of outdoor play are one-on-one fighting and community-building play activities. The major indoor play types are role-playing and activities involving socio-cognitive construction. When playing outdoors, boys prefer one-on-one fighting while girls prefer community-building play. In indoor environments, boys prefer role-playing whereas girls prefer activities requiring socio-cognitive construction. Irrespective of biological sex, preference for role-playing in an indoor environment is accompanied by low levels of fear of animals, social stimuli and sex scenes, while preference for physical and social challenges is associated with low scores of agoraphobia. Conclusions: Adults' sensitivity to specific fear-inducing stimuli are related to their preferred childhood playing environment and play types.

Keywords: agoraphobia, play, fear, environment, biological sex, indoor, outdoor 